\title{
Evaluation of immunomodulatory and anti-inflammatory effects and phytochemical screening of Alternanthera tenella Colla (Amaranthaceae) aqueous extracts
}

\author{
Carla de Agostino Biella, Marcos José Salvador', Diones Aparecida Dias², Marcelo Dias-Baruffi, \\ Luciana Simon Pereira-Crott/ ${ }^{+}$ \\ Departamento de Análises Clínicas, Toxicológicas e Bromatológicas ²Departamento de Física e Química, Faculdade de Ciências \\ Farmacêuticas de Ribeirão Preto, Universidade de São Paulo, Av. do Café s/n, 14040-903 Ribeirão Preto, SP, Brasil \\ 1Departamento de Fisiologia Vegetal, Instituto de Biologia, Universidade Estadual de Campinas, Campinas, SP, Brasil
}

\begin{abstract}
Alternanthera tenella Colla extracts are used in Brazilian traditional folk medicine to treat a variety of infectious diseases as well as inflammation and fever. In this work, the immunomodulatory, anti-inflammatory and potential toxic effects of cold (CAE) and hot (HAE) aqueous extracts of A. tenella were investigated in vivo. In addition, we analyzed the phytochemical properties of both extracts. BALB/c mice were immunized in vivo with sheep red blood cells and concomitantly inoculated intraperitoneally (i.p.) with each extract (50, 100 or $200 \mathrm{mg} / \mathrm{kg}$ ). Specific antibodyproducing cells were enumerated using plaque-forming cell assays (PFC) and anti-SRBC IgG and IgM serum levels were measured via enzyme-linked immunosorbent assay. Body and lymphoid organ weights were determined after treatments in order to evaluate toxic effects. Carrageenan-induced paw edema was employed to investigate antiinflammatory activity in mice inoculated i.p. with CAE or HAE (200 or $400 \mathrm{mg} / \mathrm{kg})$. Phytochemical screening was performed using spectrometric and chromatographic approaches and revealed that CAE possessed higher tannin and flavonoid levels than HAE. PFC numbers were increased after treatment with CAE (100 mg/kg) four days after immunization, as were the serum antibody titers after four and seven days, suggesting immunostimulatory activity through modulation of B lymphocyte functions. Body and organ weights did not show major changes, suggesting that extracts administered to mice did not induce significant toxicity. Both extracts had significant anti-inflammatory activity in the paw edema assay. These results suggested that aqueous extracts from A. tenella contained several chemical compounds that possess positive and/or negative modulator effects on the immune system, which appeared to correlate with tannin and flavonoid levels in those extracts. In summary, these studies provide important insight into the biological activities of $\mathrm{A}$. tenella.
\end{abstract}

Key words: immunomodulation - B lymphocyte - Alternanthera tenella - Amaranthaceae - plant extracts - anti-inflammatory

Utilization of natural products with therapeutic properties is as old as human civilization. For a long period of time, minerals, plants and animal products were the main sources of drugs with different properties (De Pasquale 1984). Today, many natural plant products and synthetic compounds have been evaluated for their capacity to modulate immune responses (Davis \& Kuttan 2000, Bin-Hafeez et al. 2003, Barnes et al. 2005, Cheng et al. 2005, Patwardhan \& Manish 2005). The immunomodulatory potential of Alternanthera maritima extracts and isolated flavonoids were recently investigated by our research group and it was observed that they have stimulatory activity in the humoral immune system (Uecker et al. 2003). Alternanthera, a genus belonging to the Amaranthaceae family, contains 80 species, 30 of

Financial support: CAPES (CAB fellowship), CNPq, FAPESP + Corresponding author: lupcrott@usp.br

Received 17 April 2008

Accepted 19 August 2008 which occur in Brazil (Siqueira \& Guimarães 1984). This family shows great chemical diversity in its constituents (steroids, flavonoids, alkaloids, saponins and terpenes) (Patterson et al. 1991, Salvador \& Dias 2004), but Amaranthaceae is a Brazilian flora component that has not been significantly explored. Other species evaluated have shown antitumoral (Gomphrena martiana) (Pomilio et al. 1994), analgesic (Alternanthera brasiliana) (Macedo et al. 1999) and antiviral (HIV - Alternanthera philoxeroides) (Zhang et al. 1988) activities. Alternanthera tenella Colla, a herbaceous plant commonly known as "enxuga" or "perpétua do mato," is frequently found in northwest Brazil (Guerra et al. 2003), but also occurs in other regions, like the state of São Paulo (Salvador 2005). It is used in popular medicine to treat fever, infection and inflammation (Rego 1995). Other biological activities including antibacterial (Salvador 2005) and antifungal (Salvador et al. 2003) activity, as well as viability reduction of Trypanosoma cruzi trypomastigotes and Leishmania amazonensis amastigotes (Salvador 2005) have recently been reported. Moreover, phytochemical analysis of the antioxidant ethanolic extract of $A$. tenella has also been documented and led to the isolation of six major antioxidant flavonoid constituents (Salvador et al. 2006). 
The immunomodulatory and anti-inflammatory activities of $A$. tenella were evaluated in this study based upon its utilization in popular medicine and the biological activities it has already demonstrated. Plant aqueous extracts were evaluated in the context of the BALB/c mice immune system by determining its effects on body and lymphoid organ weights, splenic cellularity, plaqueforming cells (PFC), antibody production (ELISA) and carrageenan-induced paw edema.

\section{MATERIALS AND METHODS}

Plant material and crude extract preparation - Whole A. tenella Colla (Amarantaceae) plants were collected at Alto da Boa Vista, Ribeirão Preto, São Paulo, Brazil, in May 2002, and identified by Professor Dr. JC de Siqueira (Pontifícia Universidade Católica, Rio de Janeiro, $\mathrm{RJ}$ ). A voucher specimen (register no SPFR 02968) was deposited at the herbarium of the Faculdade de Filosofia, Ciências e Letras de Ribeirão Preto, SP, Brazil. The fresh material was powdered and cold and hot $\left(50^{\circ} \mathrm{C}\right)$ distilled water crude lyophilized extracts were prepared and identified as CAE and HAE, respectively (Fig. 1). The lyophilized extracts were dissolved in pyrogenfree isotonic saline, sterilized using a Millipore filter $(0.2 \mu \mathrm{m})$ and stored at $4^{\circ} \mathrm{C}$.

Phytochemical screening of the aqueous crude extracts - Phytochemical screening of the extract was carried out using a conventional protocol (Wagner et al. 1984) for detecting the presence of different constituents like tannins, saponins, unsaturated sterols, triterpenoids, alkaloids and flavonoids. Common precipitation and coloring reagents were used to screen the CAE and HAE for phenolic compounds $\left(\mathrm{FeCl}_{3}, 2 \%\right)$ and alkaloids (Dragendorff and Mayer reagents). The extracts were monitored by TLC chromatography $(20 \times 20 \mathrm{~cm}$ glass plates, 0.25 $\mathrm{mm}$ thick, Si gel $\mathrm{GF}_{255}$, Merck, Brazil), eluted with $n$ $\mathrm{BuOH} / \mathrm{AcOH} / \mathrm{H}_{2} \mathrm{O}$ (BAW) 65:15:25, and then revealed with chromogenic spray reagents (phosphomolybdic acid $20 \%$ in $\mathrm{MeOH} w / \mathrm{v}$ and $\mathrm{p}$-anisaldehyde $0.5 \%$ in $\mathrm{H}_{2} \mathrm{SO}_{4}$ $\mathrm{w} / \mathrm{v}$, followed by heating at $110^{\circ} \mathrm{C}$ and $\mathrm{NP} / \mathrm{PEG}$ ) and exposed to NH3 vapor and UV light at 254 and $366 \mathrm{~nm}$ (Wagner \& Bladt 1996). IR spectra (KBr pellets) were recorded using a Nicolet Protégé 460 spectrometer. $1 \mathrm{H}$ NMR spectra were run with $\mathrm{D}_{2} \mathrm{O}$ on a Brucker Advance DPX 300 (3300 MHz) spectrometer.

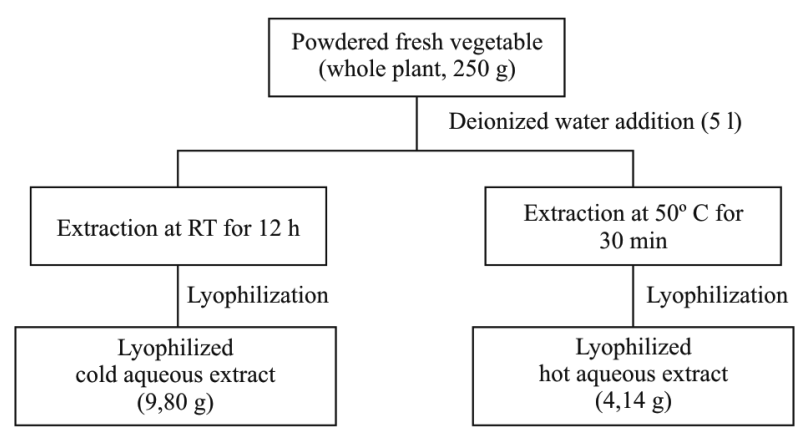

Fig. 1: a flow chart for the aqueous extraction of lyophilized fresh whole plant.
Animals - Male BALB/c mice (20-25 g) and adult guinea pigs and adult sheep were used in the study. The Central Animal House Facility of Universidade de São Paulo, Ribeirão Preto provided all animals. Mice were maintained in the Faculdade de Ciências Farmacêuticas de Ribeirão Preto, Animal House Facility. Food pellets and water were provided ad libitum. All protocols used are in accordance with the Guidelines for Ethical Care of Experimental Animals and approved by the Animal Care and Use Committee of the Institution (protocol 04.1.474.53.9).

Treatment of mice for PFC and cellularity assays Mice were separated into experimental groups $(\mathrm{n}=6)$. Positive control and treated groups were retroorbitally immunized with sheep red blood cells (SRBC) $(0.1 \mathrm{~mL}$, $25 \%$ suspension in saline) and concomitantly inoculated intraperitoneally (i.p.) with $0.2 \mathrm{~mL}$ sterile saline (positive control group) or $0.2 \mathrm{~mL}$ of CAE or HAE extracts containing 50,100 or $200 \mathrm{mg} / \mathrm{Kg}$ body weight in a single administration (treated groups). Negative controls received only $0.2 \mathrm{~mL}$ sterile saline (i.p.).

Body and lymphoid organ weights - Mouse body weights were obtained at the time of immunization (day 0 ) and 4, 7 and 14 days after the single treatment with extracts. Organ weights for the spleen, liver and thymus were determined for each animal after sacrifice by cervical dislocation four or 14 days from start of treatment according to the experiment.

Splenic cellularity - Mouse spleens for cell counting were prepared in Hank's balanced salt solution (HBSS). Four days after immunization with SRBC and administration of different treatments (as described above), the spleen was teased apart, the cells treated with $3 \mathrm{~mL}$ of erythrocyte lysis buffer $\left(0.16 \mathrm{M} \mathrm{NH}_{4} \mathrm{Cl} ; 0.17 \mathrm{M}\right.$ Tris; $\mathrm{pH}$ 7.65), washed three times and suspended in HBSS. The Neubauer chamber was used for cell counting and viability was determined by the Trypan Blue exclusion test.

$P F C$ - Four days after immunization with SRBC and different treatments in mice, the PFC assay was performed using spleen cells according to the method of Jerne and Nordin (1963). Spleen cells collected from individual animals $\left(0.1 \mathrm{~mL} ; 1 \times 10^{6}\right.$ cells $\left./ 0.1 \mathrm{~mL}\right), 0.4 \mathrm{~mL}$ of $0.5 \%$ "low melting point" agarose (GIBCO, Grand Island, NY, USA) in HBSS, and $50 \mu \mathrm{L}$ of a suspension of $5 \% \mathrm{SRBC}$ were added to test tubes at $37^{\circ} \mathrm{C}$ and poured onto microscope slides containing a bottom layer of $0.5 \%$ agarose in water. The slides were then incubated for $2 \mathrm{~h}$ at $37^{\circ} \mathrm{C}$ and $5 \% \mathrm{CO}_{2}$. Guinea pig serum diluted $1: 4$ in HBSS was added to the slides and after another $40 \mathrm{~min}$ $\left(37^{\circ} \mathrm{C}\right.$ and $\left.5 \% \mathrm{CO}_{2}\right)$ incubation the number of plaques was counted and values were expressed as PFC per $10^{6}$ cells. For the preparation of guinea pig serum as the complement source, animals were anesthetized before cardiac puncture and blood samples were collected. Serum was obtained and previously absorbed with SRBC before being stored at $-70^{\circ} \mathrm{C}$.

Preparation of SRBC membrane antigens - Partially purified SRBC membrane antigens were prepared as described by Temple et al. (1993) with some modifica- 
tions. All procedures were carried out at $4^{\circ} \mathrm{C}$. Briefly, sheep blood was collected in Alsever's solution and cells were isolated by centrifugation at $1,000 \mathrm{~g}$ for $15 \mathrm{~min}$. After removal of plasma and the buffy coat, the cells were washed with five volumes of $0.9 \% \mathrm{NaCl}$ three times. The washed pellets were suspended in approximately two volumes of $0.05 \mathrm{M}$ Tris- $\mathrm{HCl}$ with $0.1 \mathrm{mM}$ EDTA ( $\mathrm{pH} 7.6)$, were mixed thoroughly and were centrifuged at $25,000 \mathrm{~g}$ for $30 \mathrm{~min}$. This process was repeated as necessary until the supernatant became clear. The pellet suspension was further filtered through three layers of gauze, centrifuged again and resuspended in $0.1 \%$ sodium dodecyl sulfate (SDS) with $0.02 \%$ sodium azide (three times pellet volume). The solubilized membrane antigens were dialyzed against $0.1 \%$ SDS in PBS (molecular weight cut-off $12-14 \mathrm{kDa}$ ) and stored at $-20^{\circ} \mathrm{C}$. Total protein quantification was performed as described previously using the Bradford (1976) assay.

Enzyme-linked immunosorbent assay (ELISA) Anti-SRBC circulating antibody titers of mice were determined by ELISA. SRBC antigen, in aliquots of a $5 \mu \mathrm{g} / \mathrm{mL}$ suspension in PBS, pH $7.2(125 \mu \mathrm{L} / \mathrm{well})$, was incubated overnight at $4^{\circ} \mathrm{C}$ in high-binding microplates (Costar, New York, USA). Prior to each subsequent step, plates were washed three times with PBS-T $(0.05 \%$ Tween 20, Sigma-Aldrich, St Louis, MO, in PBS). Unbound sites were blocked with $3 \%$ powdered milk in PBS $(200 \mu \mathrm{L} /$ well) for $2 \mathrm{~h}$ at room temperature (RT). Serum from experimental animals diluted 1:8 in PBS-T was added to the wells $(125 \mu \mathrm{L} /$ well $)$ followed, after $1 \mathrm{~h}$ incubation at RT, by horseradish peroxidase conjugated anti-mouse $\operatorname{IgG}(1: 1000)$ and $\operatorname{IgM}(1: 2000)$ (Caltag Laboratories Inc, Burlingame, CA) diluted in PBS-T (125 $\mu \mathrm{L} /$ well). After another hour at RT, OPD substrate (Sigma Fast ${ }^{\mathrm{TM}}$ OPD, Sigma-Aldrich, St Louis, MO) was added $(200 \mu \mathrm{L} /$ well $)$ and the plates were incubated in the dark for $20 \mathrm{~min}$ at RT. The reaction was stopped with $2 \mathrm{M} \mathrm{H}_{2} \mathrm{SO}_{4}(75 \mu \mathrm{L} /$ well $)$ and the color in each well was evaluated at $490 \mathrm{~nm}$ on an ELISA reader (Spectramax Plus, Molecular Devices, Sunnyvale, CA), Softmax program.

Carrageenan-induced edema - Mice were treated i.p. with $0.2 \mathrm{~mL}$ of the aqueous extracts (CAE or HAE), 200 or $400 \mathrm{mg} / \mathrm{kg}$ or indomethacin $(5 \mathrm{mg} / \mathrm{kg})$ or sterile saline (control). After $60 \mathrm{~min}$, edema was induced with an injection of $50 \mu \mathrm{L}$ of $1 \%$ carrageenan in saline into the right hind paw. Paw thicknesses were measured using a dial caliper (Mitutoyo, Japan) immediately prior to carrageenan injection, $30 \mathrm{~min}$ after, and then at hourly intervals up to $5 \mathrm{~h}$ afterwards. Data are shown as increases in paw thickness and the difference between treated animals and controls was evaluated at the same time point after carrageenan injection. For this assay, mice were separated into six groups: (a) controls receiving the vehicle, saline, $\mathrm{n}=5$; (b) CAE extract (receiving $200 \mathrm{mg} /$ $\mathrm{kg}$ or $400 \mathrm{mg} / \mathrm{kg}, \mathrm{n}=6$ ); (c) HAE extract (receiving 200 $\mathrm{mg} / \mathrm{kg}, \mathrm{n}=5$ or $400 \mathrm{mg} / \mathrm{kg}, \mathrm{n}=6$ ); (d) indomethacin (receiving $5 \mathrm{mg} / \mathrm{kg}, \mathrm{n}=6$ ).

Statistical analysis - The results were expressed as means \pm SEM and were evaluated by one-way analysis of
variance(ANOVA), followed by the Tukey test for multiple comparisons of body weights, lymphoid organ weights, splenic cellularity evaluation, PFC and ELISA assays. Results of the carrageenan-induced edema assay (CIEA) were expressed as means \pm SD and evaluated by two-way ANOVA, followed by the Bonferroni test for multiple comparisons. Levels of significance were set at $p<0.05$.

\section{RESULTS}

Phytochemicalscreening-The phytochemical screening of the aqueous extracts using common precipitation and coloring reagents revealed the possible presence of flavonoids, tannins, glycosides and saponins. Tests for steroids, alkaloids, lactones/ester and protein/amino acids were found to be negative. Spectrometric (IR and NMR) and chromatographic (TLC) analyses of CAE and HAE suggested that flavonoids glycosides and saponins are among the main constituents that can be related with the biological activity of the extracts. The IR spectrum showed absorptions of $\mathrm{OH}$ groups $\left(3350 \mathrm{~cm}^{-1}\right)$ and aromatic rings $\left(1610,1515\right.$ and $\left.1450 \mathrm{~cm}^{-1}\right)$. The spectrum data of ${ }^{1} \mathrm{H}-\mathrm{NMR}$ showed the proton resonances commonly found on flavonoids and their substituents, such as aromatic signals between $6.0-8.0 \mathrm{ppm}$ and anomeric protons of sugars between 4.0-5.0 ppm. Moreover, several signals attributed to methyl, methylene and olefinic groups that suggested the possible presence of saponins were observed in the ${ }^{1} \mathrm{H}-\mathrm{NMR}$ spectrum (Hostettmann et al. 1991, Markham \& Geiger 1994). Sesquiterpene lactones were not detected since typical carbonyl bands of $\alpha, \beta$-unsaturated- $\gamma$-lactones were not observed in the IR spectrum between $1750-1780 \mathrm{~cm}^{-1}$, while typical olefinic protons did not appear in the NMR spectra. The results of the phytochemical analysis are shown in Table I. The number of positive signs indicated the intensity of the reactions that reflect the quantity present.

Effect of CAE and HAE extracts on body and lymphoid organ weights - Mice treated once with CAE or HAE extracts in doses of 50,100 or $200 \mathrm{mg} / \mathrm{kg}$ did not show significant differences in body and lymphoid organ weights after 4, 7 and 14 days when compared to controls

\section{TABLE I}

Phytochemical constituents of Alternanthera tenella aqueous extracts

\begin{tabular}{lcc}
\hline Parameters & CAE extract & HAE extract \\
\hline Color & Brown & Brown \\
Flavonoids & ++ & + \\
Tannins & ++ & + \\
Saponins & +++ & +++ \\
Reducing sugars & +++ & +++ \\
Alkaloids & - & - \\
Mucilage & - & - \\
Sterols and triterpenoids & - & - \\
Lactones/ester & - & - \\
\hline
\end{tabular}

+: positive test; -: negative test;,,++++++ : quantitative presence. 
TABLE II

Effect of Alternanthera tenella cold aqueous extract (CAE) on body and relative organ weights in mice

\begin{tabular}{|c|c|c|c|c|c|c|c|}
\hline \multirow[b]{2}{*}{ Groups } & \multicolumn{4}{|c|}{ Body weight (g) } & \multicolumn{3}{|c|}{ Relative organ weight $(\mathrm{mg} / \mathrm{g})^{a}$} \\
\hline & Initial & 4 days & 7 days & 14 days & Spleen & Thymus & Liver \\
\hline Negative control & $22 \pm 1$ & $24 \pm 1$ & $23 \pm 1$ & $24 \pm 1$ & $5.1 \pm 0.3$ & $2.6 \pm 0.3$ & $51.4 \pm 1.1$ \\
\hline Positive control & $22 \pm 2$ & $22 \pm 1$ & $22 \pm 0.5$ & $23 \pm 0.4$ & $5.2 \pm 0.5$ & $2.8 \pm 0.3$ & $50.7 \pm 2.8$ \\
\hline CAE $50 \mathrm{mg} / \mathrm{kg}$ & $23 \pm 1$ & $23 \pm 1$ & $22 \pm 1$ & $23 \pm 1$ & $8.4 \pm 2.1$ & $2.7 \pm 0.3$ & $52.8 \pm 2.1$ \\
\hline CAE $100 \mathrm{mg} / \mathrm{kg}$ & $22 \pm 1$ & $23 \pm 1$ & $22 \pm 1$ & $23 \pm 1$ & $7.6 \pm 1.2$ & $2.4 \pm 0.3$ & $53.9 \pm 2.0$ \\
\hline $\mathrm{CAE} 200 \mathrm{mg} / \mathrm{kg}$ & $23 \pm 1$ & $24 \pm 1$ & $23 \pm 1$ & $24 \pm 1$ & $6.8 \pm 1.0$ & $2.8 \pm 0.3$ & $53.1 \pm 2.3$ \\
\hline
\end{tabular}

$a$ : organ weight (mg)/body weight $(\mathrm{g}) 14$ days after treatment; values are means $\pm \operatorname{SEM}(\mathrm{n}=6)$.

TABLE III

Effect of Alternanthera tenella hot aqueous extract (HAE) on body and relative organ weights in mice

\begin{tabular}{|c|c|c|c|c|c|c|c|}
\hline \multirow[b]{2}{*}{ Groups } & \multicolumn{4}{|c|}{ Body weight (g) } & \multicolumn{3}{|c|}{ Relative organ weight $(\mathrm{mg} / \mathrm{g})^{a}$} \\
\hline & Initial & 4 days & 7 days & 14 days & Spleen & Thymus & Liver \\
\hline Negative control & $22 \pm 1$ & $23 \pm 1$ & $22 \pm 1$ & $22 \pm 1$ & $4.8 \pm 0.3$ & $2.5 \pm 0.1$ & $50.5 \pm 1.4$ \\
\hline Positive control & $23 \pm 1$ & $24 \pm 1$ & $23 \pm 1$ & $24 \pm 1$ & $7.7 \pm 1.9$ & $2.8 \pm 0.3$ & $56.4 \pm 3.9$ \\
\hline $\mathrm{HAE} 50 \mathrm{mg} / \mathrm{kg}$ & $23 \pm 1$ & $23 \pm 1$ & $23 \pm 0.2$ & $24 \pm 0.2$ & $5.4 \pm 0.3$ & $2.7 \pm 0.2$ & $50.4 \pm 1.9$ \\
\hline HAE 100 mg/kg & $22 \pm 1$ & $22 \pm 0.4$ & $22 \pm 1$ & $22 \pm 1$ & $6.5 \pm 1.1$ & $2.5 \pm 0.2$ & $50.7 \pm 0.8$ \\
\hline HAE 200 mg/kg & $22 \pm 1$ & $22 \pm 1$ & $22 \pm 1$ & $23 \pm 1$ & $7.2 \pm 0.9$ & $2.5 \pm 0.4$ & $53.7 \pm 1.2$ \\
\hline
\end{tabular}

$a$ : organ weight (mg)/body weight $(\mathrm{g}) 14$ days after treatment; values are means \pm SEM $(\mathrm{n}=6)$.

TABLE IV

Effect of Alternanthera tenella larger doses of cold aqueous extract (CAE) and hot aqueous extract (HAE) on body and relative organ weights in mice

\begin{tabular}{lcccc}
\hline & & & \multicolumn{2}{c}{${\text { Relative organ weight }(\mathrm{mg} / \mathrm{g})^{b}}^{b}$} \\
\cline { 3 - 5 } Groups $^{a}$ & Body weight $(\mathrm{g})$ & Spleen & Thymus & Liver \\
\hline Control $^{c}$ & $24.8 \pm 1.3$ & $4.3 \pm 0.3$ & $2.3 \pm 0.3$ & $49.2 \pm 0.7$ \\
CAE $200 \mathrm{mg} / \mathrm{kg}$ & $23.7 \pm 0.9$ & $4.1 \pm 0.0$ & $2.6 \pm 0.2$ & $47.2 \pm 1.3$ \\
CAE $400 \mathrm{mg} / \mathrm{kg}$ & $24.9 \pm 2.0$ & $4.8 \pm 0.3$ & $3.2 \pm 0.3$ & $58.8 \pm 1.3^{d}$ \\
HAE $200 \mathrm{mg} / \mathrm{kg}$ & $22.7 \pm 1.1$ & $4.2 \pm 0.1$ & $2.2 \pm 0.4$ & $45.7 \pm 2.1$ \\
HAE 400 mg/kg & $24.9 \pm 1.7$ & $3.9 \pm 0.3$ & $2.3 \pm 0.2$ & $47.2 \pm 0.7$ \\
\hline
\end{tabular}

$\bar{a}$ : mice used in the carrageenan induced paw edema assay; $b$ : organ weight (mg)/body weight (g) 14 days after treatment; values are means $\pm \operatorname{SEM}(\mathrm{n}=5$ or 6$) ; c$ : animals treated with carrageenan and saline; $d: \mathrm{p}<0.01$ when compared with control group.

(Tables II, III). Body weights are expressed in absolute values and relative organ weights as organ weight (mg)/ body weight $(\mathrm{g})$. Another groups of mice treated i.p. with CAE or HAE extracts in doses of 200 or $400 \mathrm{mg} /$ $\mathrm{kg}$ (CIEA) also did not demonstrate an organ weight decrease (Table IV). However, mice treated with CAE 400 $\mathrm{mg} / \mathrm{kg}$ displayed a liver weight increase of $19.5 \%$.

Effect of CAE or HAE extracts on spleen cellularity - Spleen cellularity data did not indicate significant increases in treated mice at any of the doses (Fig. 2) when compared to the positive control group (animals immunized with SRBC). The positive control groups showed an increase in cellularity $(p<0.01-$ CAE; $p<0.001$ HAE) when compared with negative controls (saline), demonstrating immunization efficiency. Cell viability was approximately $90 \%-88 \%$ in CAE or HAE-treated mice, respectively.
Effect of CAE or HAE extracts in the PFC assay The effect of CAE or HAE extracts on PFC production is shown in Fig. 3. Mice treated with CAE $100 \mathrm{mg} / \mathrm{kg}$ showed a significant increase $(p<0.05)$ when compared to the control groups (Fig. 3A). However, no significant effect was seen in animals treated with CAE 50 and $200 \mathrm{mg} /$ $\mathrm{kg}$. Treatment with HAE at all doses did not induce significant increases in PFC numbers, but a dose-dependent increased tendency in PFC production was observed and shown in Fig. 3B.

Effect of CAE or HAE extracts on circulating antibody titers - SRBC membrane antigen was prepared as described in Material and Methods and contained 0.793 $\mathrm{mg} / \mathrm{mL}$ of protein. Anti-SRBC antibody IgM and IgG titers were measured in mice serum of different groups, collected retroorbitally on $0,4,7$ and 14 days after immunization and treatment. Anti-SRBC IgM and IgG ti- 
ters increased in immunized and CAE-treated mice as shown in Fig. 4. A significant IgM titer increase was observed for doses 50,100 and $200 \mathrm{mg} / \mathrm{kg}(\mathrm{p}<0.05$, $\mathrm{p}<0.01$ and $\mathrm{p}<0.01$, respectively - Fig. 4B) in comparison to the positive control, four days after immunization and treatment. The increase was also observed in animals immunized and treated with $50 \mathrm{mg} / \mathrm{kg}(\mathrm{p}<0.05)$ compared to positive controls seven days after treatment (Fig. 4C). IgG titers also increased significantly in mice treated with three doses of CAE 50,100 and $200 \mathrm{mg} / \mathrm{kg}$ $(\mathrm{p}<0.01, \mathrm{p}<0.05$ and $\mathrm{p}<0.05$, respectively) after seven days (Fig. 4C) when compared with immunized-only mice (positive control). A similar profile was obtained after 14 days, but the differences were not significant (Fig. 4D). No significant effect in antibody titers was observed after treatments with HAE extracts in immunized animals for any of the doses or periods evaluated (Fig. 5).
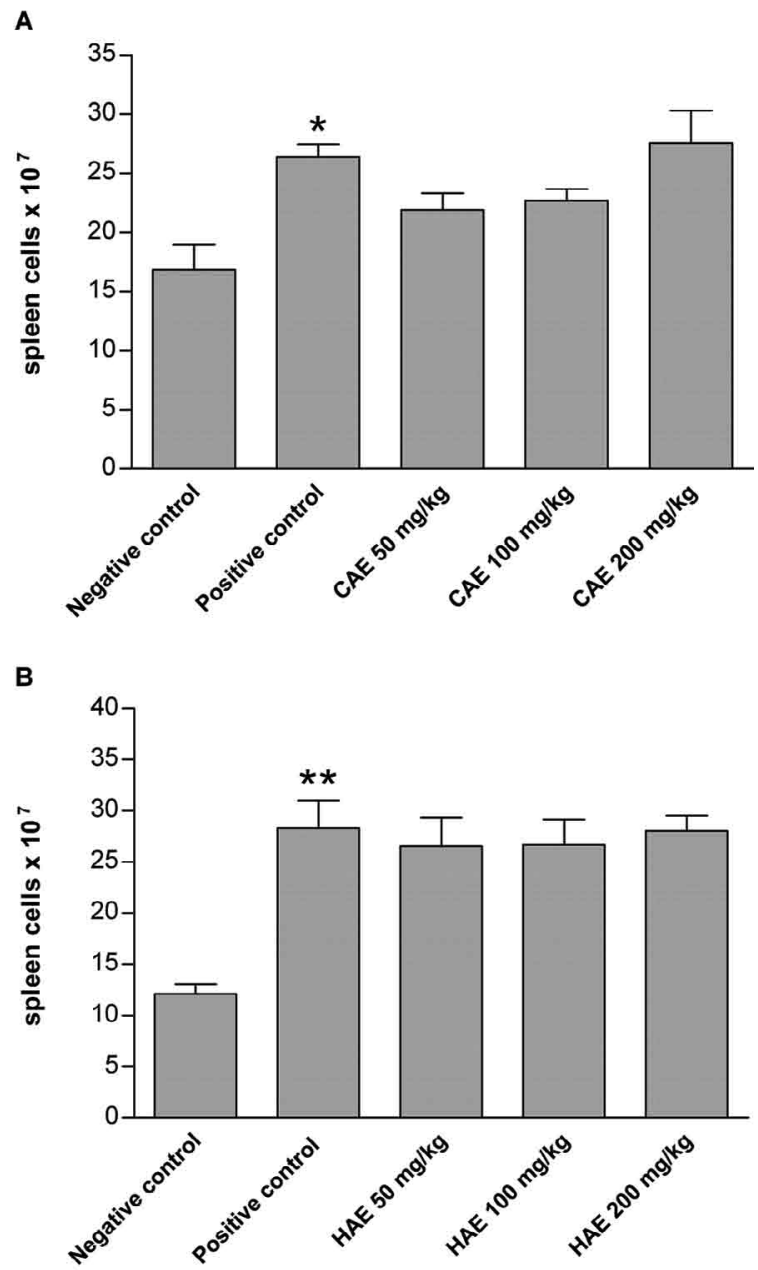

Fig. 2: effect of Alternanthera tenella cold aqueous extract (CAE) (A) or hot aqueous extract (HAE) (B) extracts on mice spleen cellularity. Data are means \pm SEM of six animals. Mice immunized with sheep red blood cells (SRBC) were concomitantly treated with CAE or HAE in doses of $50 \mathrm{mg} / \mathrm{kg}, 100 \mathrm{mg} / \mathrm{kg}$ or $200 \mathrm{mg} / \mathrm{kg}$. Four days after immunization, spleen cells were counted. $*: \mathrm{p}<0.01 ; * *$ : $<0.001$, when compared with negative control group. Negative control: mice treated with sterile saline; positive control: mice immunized with SRBC and treated with sterile saline.
Effect of CAE and HAE extracts on carrageenan-induced edema - Fig. 6 shows that injection of carrageenan in the control group induced acute inflammation with a prominent increase in paw thickness, beginning $1 \mathrm{~h}$ after intraplantar injection and reaching a peak of inflammation after 3 and 4 h. i.p. administration of CAE at 200 or $400 \mathrm{mg} / \mathrm{kg}, 1 \mathrm{~h}$ before the carrageenan injection, induced dose-dependent edema inhibition. CAE $200 \mathrm{mg} /$ $\mathrm{kg}$, induced $42 \%$ inhibition $(\mathrm{p}<0.01)$ after the first hour and $50 \%(\mathrm{p}<0.001)$ after $3 \mathrm{~h}$. A higher dosage of the extract $(400 \mathrm{mg} / \mathrm{kg})$ inhibited the edema by $61 \%$ and $60 \%$ $(p<0,001)$ after three and four hours, respectively (Fig. $6 \mathrm{~A})$, an effect that was even higher than that of indomethacin $(5 \mathrm{mg} / \mathrm{kg})$, the anti-inflammatory drug used in the positive control. Indomethacin reduced the edema by a maximum of $55 \%(\mathrm{p}<0.001)$ after $3 \mathrm{~h}$. HAE extracts at a dose of $200 \mathrm{mg} / \mathrm{kg}$, inhibited edema by $40 \%(\mathrm{p}<0.01)$
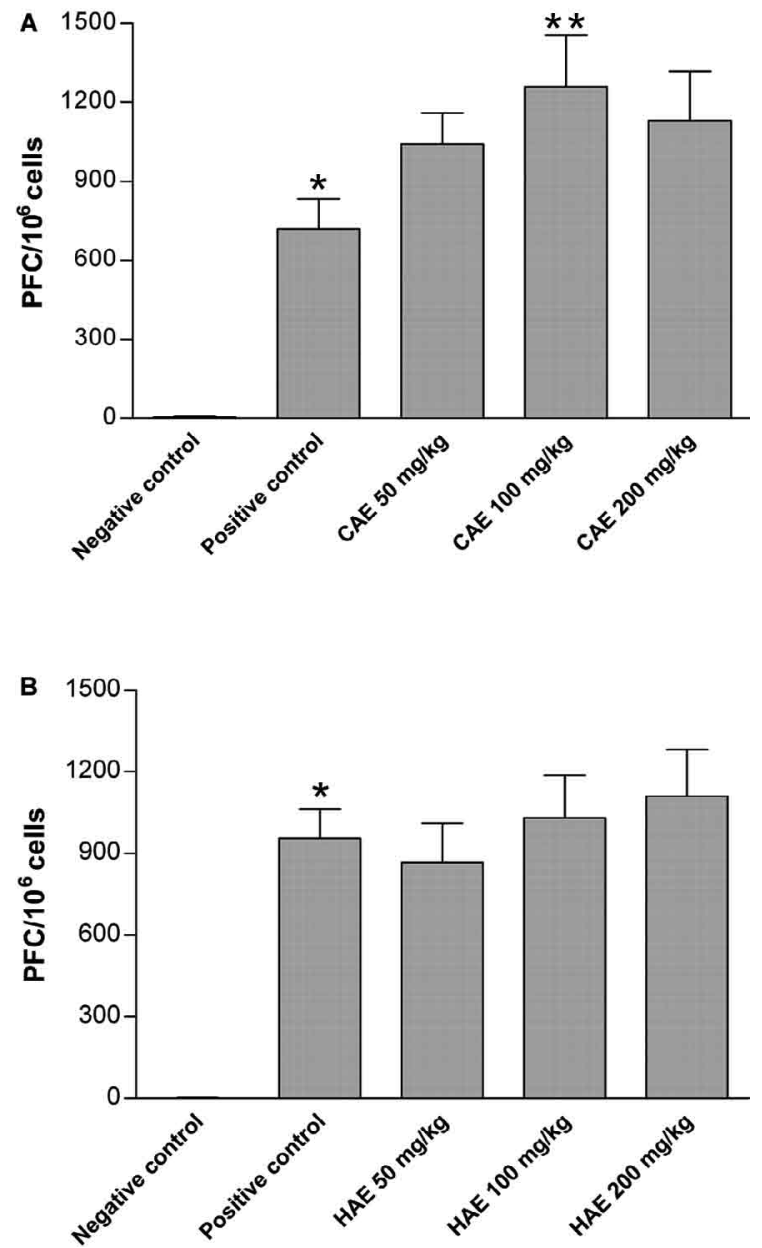

Fig. 3: effect of Alternanthera tenella cold aqueous extract (CAE) (A) or hot aqueous extract (HAE) (B) extracts plake-forming cell numbers (PFC). Data are means \pm SEM of six animals. Mice immunized with sheep red blood cells (SRBC) were concomitantly treated with CAE or HAE in doses of $50 \mathrm{mg} / \mathrm{kg}, 100 \mathrm{mg} / \mathrm{kg}$ or $200 \mathrm{mg} / \mathrm{kg}$. Four days after immunization, PFC was enumerated in spleen cells. ${ }^{*}: \mathrm{p}<$ 0.01 , when compared with negative control group; $* *$ : $<0.05$ when compared to positive control group. Negative control: mice treated with sterile saline; positive control: mice immunized with SRBC and treated with sterile saline. 



B

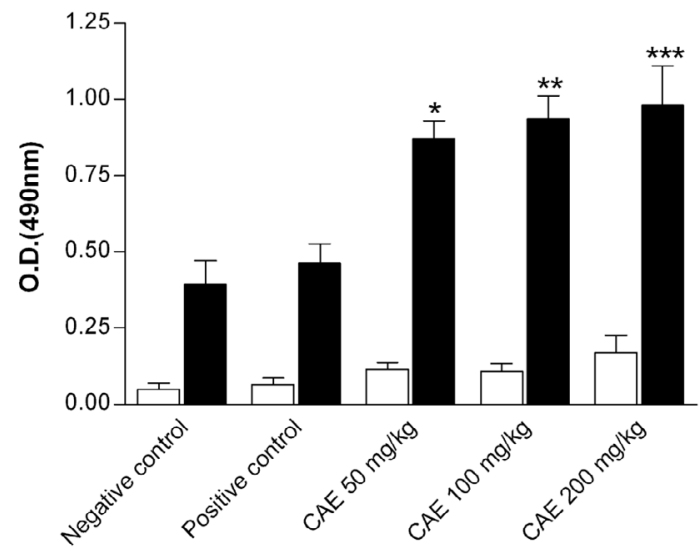

D

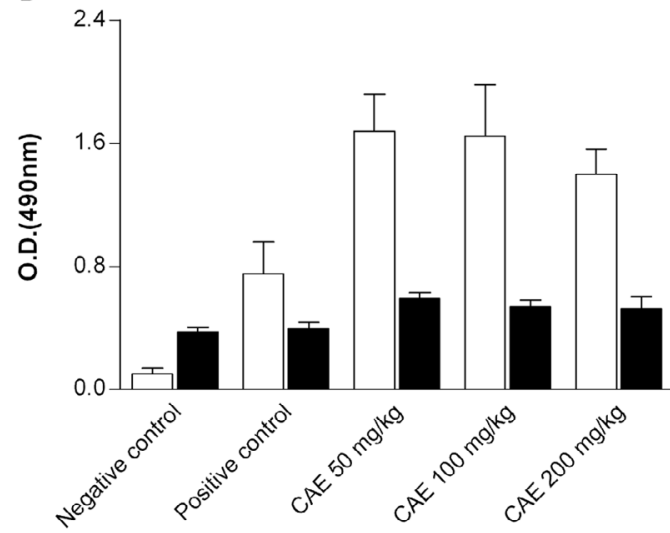

$\lg G$

Fig. 4: effect of Alternanthera tenella cold aqueous extract (CAE) on anti-sheep red blood cells (SRBC) antibody IgM and IgG titers on days 0 (A), 4 (B), 7 (C) and 14 (D) after mice immunization. Data are means \pm SEM of four to six animals. Mice immunized with SRBC and treated with CAE in doses: $50 \mathrm{mg} / \mathrm{kg}, 100 \mathrm{mg} / \mathrm{kg}$ or $200 \mathrm{mg} / \mathrm{kg}$; $: \mathrm{p}<0.05$, when compared with positive control group; **: $<<0.01$, when compared with positive control group. Negative control: mice treated with sterile saline; positive control: mice immunized with SRBC and treated with sterile saline.

only at the first hour. More effectively, HAE $400 \mathrm{mg} / \mathrm{kg}$ inhibited edema $2 \mathrm{~h}$ after carrageenan administration, reaching a maximum of $56 \%(\mathrm{p}<0.001)$ at $3 \mathrm{~h}$ (Fig. 6B).

\section{DISCUSSION}

The therapeutic potential of several plant species and the necessity for scientific validation of the use of plants in popular medicine have prompted increased interest in the field. A large number of plant species and their components have been shown to be potential immunomodulators acting as anti-inflammatory, antistress and anticancer agents (Bin-Hafeez et al. 2003). In this study, we investigated the immunomodulatory/immunotoxic and anti-inflammatory effects of aqueous extracts of A. tenella obtained in different conditions. The results suggest that $A$. tenella contains immunomodulators, in accordance with previous studies (Moraes et al. 1994, Silveira 2000, Guerra et al. 2003).

After four and 14 days of i.p. administration, extracts CAE and HAE did not alter spleen weights in mice at the concentrations evaluated. A decrease in spleen weight would be indicative of immunotoxicity (Doi et al. 1996). Other organs like the liver and thymus, also involved in toxic conditions, did not show significant differences in weight in comparison to controls when the animals were treated by doses of 50,100 and $200 \mathrm{mg} / \mathrm{kg}$ of both extracts. However, the increase in liver weight in mice treated with CAE $400 \mathrm{mg} / \mathrm{kg}$ could be attributed to a toxic effect. Liver enlargement occurs in animals and humans as a result of physiological adaptation, metabolic abnormalities, toxic effects, inflammatory processes or proliferative diseases (Williams \& Iatropoulos 2002). However, we could not positively identify a relevant toxic effect from this result since histopathological examination and/or biochemical measurements were not performed in this study.

The PFC assay is considered to be one of the most highly predictive single assays for detection of the immunomodulatory/immunotoxic potential of several substances and drugs. It was used to assess potential modulation of the humoral immune response, which quantifies the number of B cells producing SRBC-specific IgM (Wilson et 

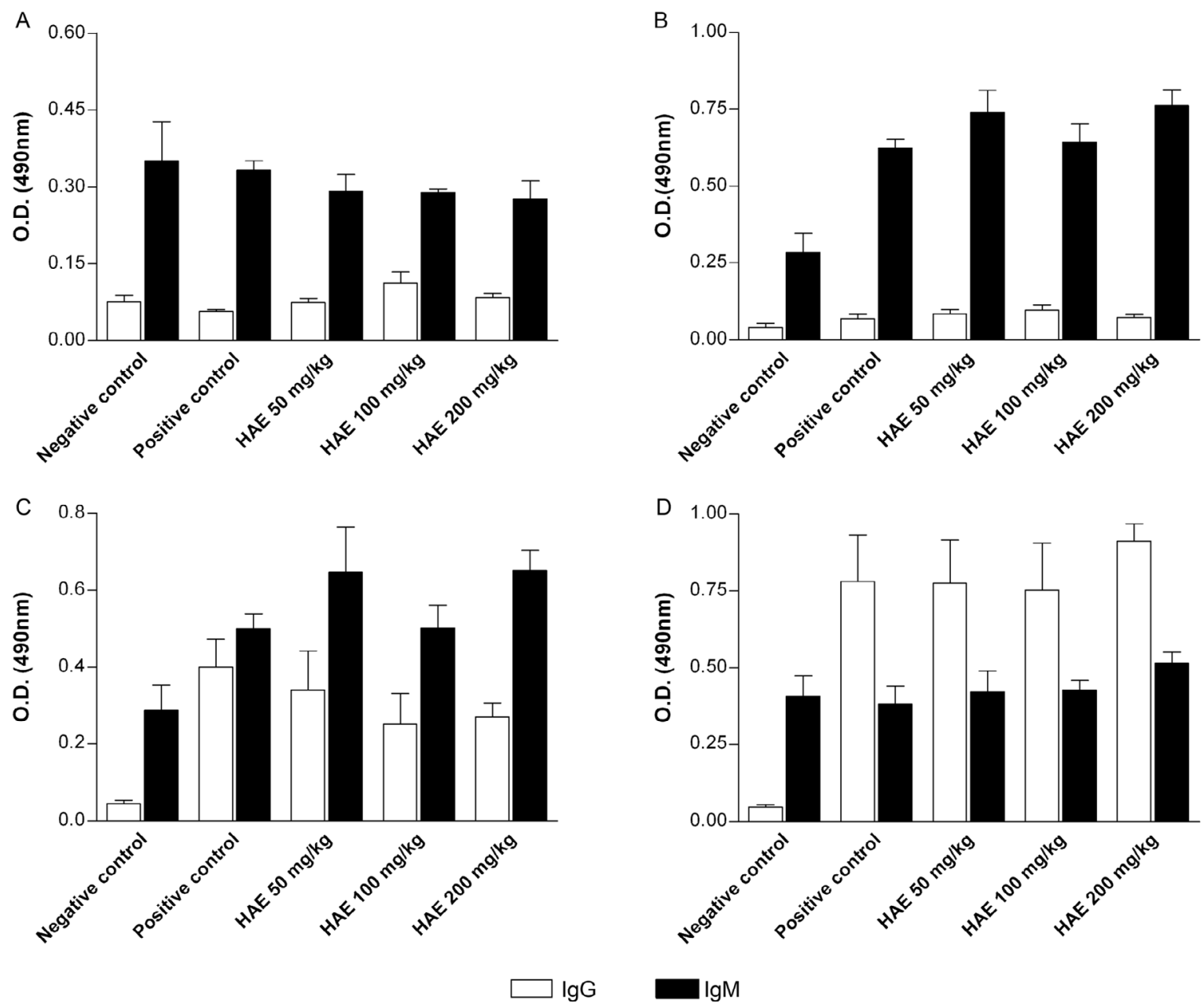

Fig. 5: effect of Alternanthera tenella hot aqueous extract (HAE) on anti-sheep red blood cells (SRBC) antibody IgM and IgG titers on days 0 (A), 4 (B), 7 (C) and 14 (D) after mice immunization. Data are means \pm SEM of four to six animals. Mice immunized with SRBC and treated with $\mathrm{HAE}$ in doses of: $50 \mathrm{mg} / \mathrm{kg}, 100 \mathrm{mg} / \mathrm{kg}$ or $200 \mathrm{mg} / \mathrm{kg}$. Negative control: mice treated with sterile saline; positive control: mice immunized with SRBC and treated with sterile saline.

al. 1999). It is considered that substances and preparations inducing PFC increases are immunostimulators (Davis \& Kuttan 2000). The increased number of PFCs in animals treated with $100 \mathrm{mg} / \mathrm{kg}$ of CAE $(\mathrm{p}<0.05)$ therefore suggests the presence of immunomodulators. Previous studies in our laboratory showed similar results for A. mariti$m a$ (M Uecker, unpublished observations). HAE or CAE water root extracts of the plant in $100 \mathrm{mg} / \mathrm{kg}$ doses were able to induce an increase in PFCs.

In this study, the increased anti-SRBC IgM titers four days after treatment with the three doses of CAE $(\mathrm{p}<0.05, \mathrm{p}<0.01, \mathrm{p}<0.01$, respectively) and after seven days with the lower dosage, in addition to increased $\operatorname{IgG}$ titers after seven days treatment, reinforces the hypothesis concerning immunomodulatory extract properties.

In contrast with our results, Guerra et al. (2003), using the same method employed in the present study (anti-SRBC IgM-producing cells/PFC), demonstrated that the aqueous extract of A. tenella $(5 \mathrm{mg} / \mathrm{kg})$ caused a significant reduction of anti-SRBC IgM-specific cells. At a higher dose $(50 \mathrm{mg} / \mathrm{kg})$, the same extract had no effect on IgM specific response. According to these authors, this immunosupressive activity of inhibiting production of antibodies to T-dependent antigens could be concomitant with immunostimulant properties increasing production of mitogen-induced antibodies. The present study demonstrated that $100 \mathrm{mg} / \mathrm{kg}$ of CAE, administered concomitantly with the immunization with SRBC, increased the number of anti-SRBC PFCs. Doses of 50 and $200 \mathrm{mg} / \mathrm{kg}$ showed no differences in PFC numbers (Fig. 3A). However, anti-SRBC IgM and IgG serum titers as measured by ELISA were significantly enhanced after administration of the three doses of CAE $(50,100$ and $200 \mathrm{mg} / \mathrm{kg}$ ) four and seven days after immunization with SRBC, respectively (Figs 4A, B). We can speculate that these differences between our results and those of Guerra et al. (2003) may be due to variations in mouse strain (Swiss vs. BALB/c), route of antigen administration (i.p. vs i.v.), scheme/timing of extract administration (previous vs concomitant to immunization) and sensitivity of antibody detection methods (PFC vs ELISA). In addition, such differences may be attributed to variation in 

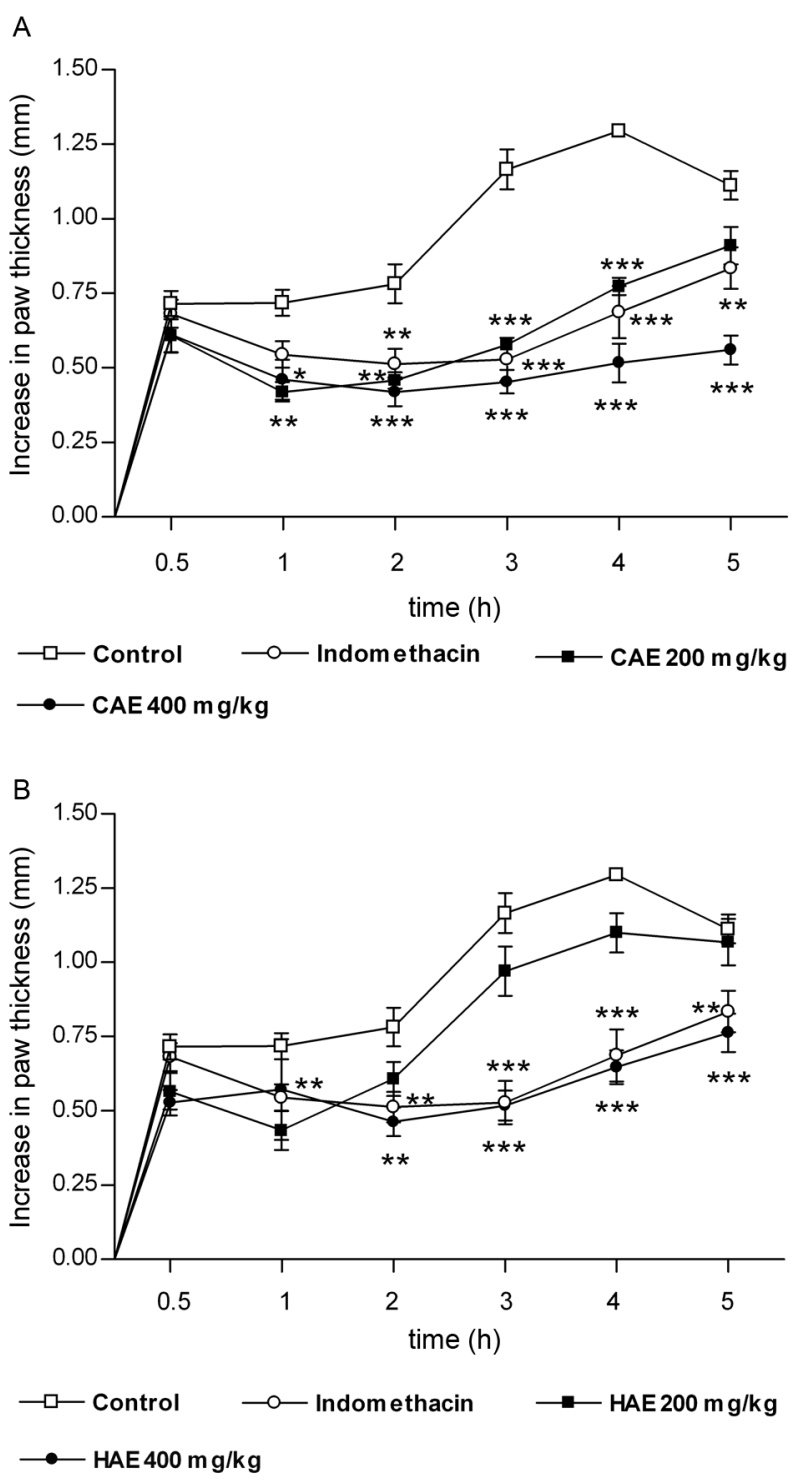

Fig. 6: effect of Alternanthera tenella cold aqueous extract (CAE) (A) or hot aqueous extract (HAE) (B) on carrageenan induced paw edema in mice. Data are means \pm SD. Mice treated with CAE $200 \mathrm{mg} / \mathrm{kg}$ $(\mathrm{n}=6)$ and CAE $400 \mathrm{mg} / \mathrm{kg}(\mathrm{n}=6)$. Mice treated with HAE $200 \mathrm{mg} / \mathrm{kg}$ $(\mathrm{n}=5)$ and HAE $400 \mathrm{mg} / \mathrm{kg}(\mathrm{n}=6) ;{ }^{*}: \mathrm{p}<0.05 ;{ }^{* *}: \mathrm{p}<0.01$; $^{* * *}: \mathrm{p}<0.001$ when compared with control group. Control: mice treated with sterile saline $(\mathrm{n}=5)$; indomethacin: mice treated with indomethacin $5 \mathrm{mg} / \mathrm{kg}(\mathrm{n}=6)$.

the chemical composition of plants according to the geographical area and the time or season of collection. Differences in the plant parts used and extract preparation process may also explain the discrepancy in the results.

The carrageenan-induced paw edema assay, conducted to evaluate anti-inflammatory activity (Winter et al. 1962) in A. tenella extracts, is a frequently used and adequate model used since 1962 in rodents, and is believed to be biphasic. The first phase involves serotonin, histamine and kinin release followed by a second phase, which is mediated by prostaglandin and cyclooxygenase products (Vinegar et al. 1969). In the present study, the paw edema was significantly reduced by 200 or $400 \mathrm{mg} /$ $\mathrm{kg}$ of CAE extract $(\mathrm{p}<0.001)$ and $400 \mathrm{mg} / \mathrm{kg}$ of HAE $(\mathrm{p}<0.001)$. The pattern of anti-inflammatory activity exhibited by $A$. tenella extracts, which is similar to that of indomethacin used as positive control in this study, tend to suggest that the plant activity may at least be partially mediated by cyclooxygenase -1 and -2 inhibition. Moraes et al. (1994) suggest that the blockade of lymphocyte proliferation by a component isolated from A. tenella may contribute to the plant anti-inflammatory properties since stimulated lymphocytes secret cytokines which attract neutrophils during the inflammatory process. The results of the paw edema assay prompt the hypothesis that CAE has components with immunosupressive activity alongside others, which could be immunostimulatory since stimulation of PFC was demonstrated. Several other plant extracts have also been shown to have simultaneous immunosupressive and immunostimulatory effects (Yamaguchi 1992, Mediratta et al. 2002).

The aqueous extracts of $A$. tenella were obtained by maceration with the same proportion of the powdered fresh plant and solvent mass $(1: 20 \mathrm{mpl} / \mathrm{msol})$ at RT $\left(27^{\circ} \mathrm{C}\right)$ and at $50^{\circ} \mathrm{C}$, with time of extraction being $12 \mathrm{~h}$ and $30 \mathrm{~min}$ for CAE and HAE extraction, respectively (Fig. 1). The different time in extraction can lead to different contents for the active compounds in the lyophilized aqueous extracts prepared. In addition, the CAE extract yield was $9.80 \mathrm{~g}$, while the HAE yield was 4.14 $\mathrm{g}$ from the same mass of powdered fresh plant $(250 \mathrm{~g})$. The cold water can lead to the extraction of distinct compounds with the same class of secondary metabolites in comparison with hot water or at different concentrations, in spite of the increase in temperature. These facts, at least partly, can justify the difference in the biological activity observed for the extracts CAE and HAE. The difference between the extract effects could be also due to the presence of constituents not extracted or destroyed depending on the extraction process.

The initial chemical characterization of the A. tenel$l a$ aqueous extracts has demonstrated the occurrence of flavonoids, tannins, glycosides and saponins. Flavonoid heterosides, like quercetin, isorhamnetin and kaempferol, could be present as aglycone. These flavonoids were previously isolated in the phytochemical studies performed with the ethanol extracts of this plant (Salvador et al. 2006). Flavonoids have many pharmacologic properties including immunomodulatory, anti-oxidant and anti-inflammatory activities (Ielpo et al. 2000) and its presence in the extracts could explain, at least partially, the results obtained in this work.

As a whole, our results contribute to a comprehensive understanding of the plant's biological properties and provide a scientific foundation for its popular use.

\section{ACKNOWLEDGEMENTS}

To Professor Dr. JC de Siqueira, for the botanical identification of plant material, Dra. Glória Emilia Petto de Souza, for her helpful suggestions and discussions during the course of this work, Ms. Ana Cristina Morseli Polizello, for helping in the blood samplings of the guinea pigs, Ms. Ana Elisa CS 
Azzolini, for her help in the preparation of SRBC membrane antigen, and Tânia Mara Casare Ogasawara and Rubens Eduardo da Silva, for skillful technical assistance.

\section{REFERENCES}

Barnes J, Anderson LA, Gibbons S, Phillipson JD 2005. Echinacea species (Echinacea angustifolia (DC.) Hell., Echinacea pallida (Nutt.) Nutt., Echinacea purpurea (L.) Moench): a review of their chemistry, pharmacology and clinical properties. J Pharm Pharmacol 57: 929-954.

Bin-Hafeez B, Haque R, Parvez S, Pandey S, Sayeed I, Raisuddin S 2003. Immunomodulatory effects of fenugreek (Trigonella foenum graecum L.) extract in mice. Int Immunopharmacol 3: 257-265.

Bradford MM 1976. A rapid and sensitive method for the quantitation of microgram quantities of protein utilizing the principle of protein-dye binding. Anal Biochem 72: 248-254.

Cheng W, Li J, You T, Hu C 2005. Anti-inflammatory and immunomodulatory activities of the extracts from the inflorescence of Chrysanthemum indicum Linné. J Ethnopharmacol 101: 334-337.

Davis L, Kuttan G 2000. Immunomodulatory activity of Withania somnifera. J Ethnopharmacol 71: 193-200.

De Pasquale A 1984. Pharmacognosy: the oldest modern science. J Ethnopharmacol 1: 1-16.

Doi T, Nagai H, Tsukuda R, Suzuki T 1996. Dose-response relationships, PFC response and histology in the spleen in rats treated with alkylating agents. Toxicology 107: 47-60.

Guerra RNM, Pereira H-AW, Silveira LMS, Olea RSG 2003. Immunomodulatory properties of Alternanthera tenella Colla aqueous extracts in mice. Braz J Med Biol Res 36: 1215-1219.

Hostettmann K, Hostettmann M, Marston A 1991. Saponins. In PM Dey, JB Harbome Methods in plants biochemistry, Vol. 7, Springer, Berlin, p. 435-471.

Ielpo MTL, Basile A, Miranda R, Moscatiello V, Nappo C, Sorbo S, Laghi E, Ricciardi MM, Ricciardi L, Vuotto ML 2000. Immunopharmacological properties of flavonoids. Fitoterapia 71 (Suppl.): S101-S109.

Jerne NK, Nordin AA 1963. Plaque formation in agar by single antibody producing cells. Science 140: 405.

Macedo AF, Barbosa NC, Esquibel MA, Souza MN, Cechinel-Filho V 1999. Pharmacological and phytochemical studies of callus culture extracts from Alternanthera brasiliana. Pharmazie 54: 776-777.

Markham KR, Geiger H 1994. 'H nuclear magnetic resonance spectroscopy of flavonoids and their glycosides in hexadeuterodimetylsulfoxide. In JB Harbone, The flavonoids, Chapman and Hall, London, p. 450-453.

Mediratta PK, Sharma KK, Singh S 2002. Evaluation of immunomodulatory potential of Ocimum sanctum seed oil and its possible mechanism of action. J Ethnopharmacol 80: 15-20.

Moraes VJG, Santos LFM, Castro SB, Loureiro LH, Lima OA, Souza MLM, Yien LMK, Rossi-Bergmann B, Costa SS 1994. Inhibition of lymphocyte activation by extracts and fractions of Kalanchoe, Alternanthera, Paullinia and Mikania species. Phytomedicine 1: 199-204.

Patterson WG, Xu S, Salt TA 1991. Sterol of Caryophyllales with emphasis on Amaranthaceae. Phytochemistry 30: 523-526.

Patwardhan B, Manish G 2005. Botanical immunodrugs: scope and opportunities. Drug Discov Today 10: 495-502.
Pomilio AB, Solá GAR, Mayer AMS 1994. Antitumor and cytotoxic screen of 5,6,7-trisubstituted flavones from Gomphrena martiana. J Ethnopharmacol 44: 25-33.

Rego TJA 1995. Fitogeografia das Plantas Medicinais no Maranhão, 2nd ed., EDUFMA, São Luís, 133 pp.

Salvador MJ 2005. Estudo químico, biológico e biotecnológico de Alternanthera maritima e Alternanthera tenella (Gomphreneae, Amaranthaceae). PhD Thesis, Faculdade de Filosofia, Ciências e Letras de Ribeirão Preto, Universidade de São Paulo, Ribeirão Preto, São Paulo, 407 pp.

Salvador MJ, Dias DA 2004. Flavone C-glycosides from Alternanthera maritima (Mart) St. Hill. (Amaranthaceae). Biochem Syst Ecol 32: 107-110.

Salvador MJ, Ferreira EO, Mertens-Talcott SU, Castro WV, Butterweck V, Derendorf H, Dias DA 2006. Isolation and HPLC quantitative analysis of antioxidant flavonoids from Alternanthera tenella Colla. Z Naturforsch 61: 19-25.

Salvador MJ, Ferreira JC, Zuleta LMC, Bolzani VS, Dias DA, Candido RC 2003. Antifungal susceptibility tests of crude extracts from Alternanthera maritima, A. tenella Colla and Calycophyllum spruceanum Benth against four Candida ssp determined by agar-well diffusion and Broth macrodilution methods. Braz J Pharm Sci 39: 240.

Silveira LMS 2000. Caracterização fitoquímica, biológica e mineral de partes aéreas de Alternanthera tenella Colla (Amaranthaceae). Msc Thesis, Universidade Federal do Maranhão, São Luís, Maranhão, 134 pp.

Siqueira JC, Guimarães EF 1984. Amaranthaceae no Rio de Janeiro gênero Alternanthera forsskal. Rodriguésia 36: 21-40.

Temple L, Kawabata TT, Munson AE, White Jr KL 1993. Comparison of ELISA and plaque-forming cells assays for measuring the humoral immune response to SRBC in rats and mice treated with benzo[a]pyrene or cyclophosphamide. Fundam Appl Toxicol 21: 412-419.

Uecker M, Biella CA, Salvador MJ, Ogasawara TMC, Dias DA, Pereira-Crott LSP 2003. Screening of Alternanthera maritima extracts for immunomodulatory activity. Braz J Pharm Sci 39: 249.

Vinegar R, Schreiber W, Hugo R 1969. Biphasic development of carrageenan oedema in rats. $J$ Pharmacol Exp Ther 166: 96-103.

Wagner H, Bladt S 1996. Plant drug analysis: a thin-layer chromatography atlas, 2nd ed., Springer, Berlin, $384 \mathrm{pp}$

Wagner H, Bladt S, Zgainski EM 1984. Plant drug analysis, SpringerVerlag, New York, xiii +320 pp.

Williams GM, Iatropoulos MJ 2002. Alteration of liver cell function and proliferation: differentiation between adaptation and toxicity. Toxicol Pathol 30: 41-53.

Wilson SD, Munson AE, Meade BJ 1999. Assessment of the functional integrity of the humoral immune response: the plaqueforming cell assay and the enzyme-linked immunosorbent assay. Methods 19: 3-7.

Winter CA, Risley EA, Nuss GW 1962. Carrageenan-induced edema in hind paw of the rat as an assay for anti-inflammatory drugs. Proc Soc Exp Biol Med 111: 544-547.

Yamaguchi H 1992. Immunomodulation by medicinal plants. $A d v$ Exp Med Biol 319: 287-297.

Zhang SM, He YS, Tabba JD, Smith KM 1988. Inhibitor against the human immunodeficiency virus in aqueous extract of Alternanthera philoxeroides. Chin Med J 101: 861-866. 